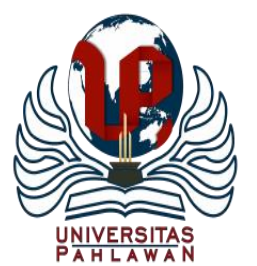

Jurnal Basicedu Volume 5 Nomor 1 Tahun 2021 Halaman 165-177

JURNAL BASICEDU

Research \& Learning in Elementary Education

https://jbasic.org/index.php/basicedu

\title{
Model Pembelajaran Numbered Head Together (NHT) pada Materi Pokok Relasi dan Fungsi
}

\author{
Agnes Pendy ${ }^{1}$, Hilaria Melania Mbagho ${ }^{2}$ \\ Pendidikan Matemetika, Universitas Flores, Nusa Tenggara Timur, Indonesia ${ }^{1,2}$ \\ Email: agnespendy@gmail.com ${ }^{1}$ hilariambagho311291@gmail.com ${ }^{2}$
}

\begin{abstract}
Abstrak
Permasalahan yang dihadapi oleh siswa di SMPN 1 Bajawa Utara yakni kurangnya partisipasi siswa dalam proses belajar mengajar disebabkan guru cenderung menggunakan metode pembelajaran yang masih bersifat konvensional, sehingga siswa tidak mendapat kesempatan untuk berpikir maupun mengungkapkan pendapat baik secara individu ataupun kelompok. Untuk mengatasi masalah tersebut, guru harus memilih metode pembelajaran yang sesuai. Salah satunya adalah pembelajaran kooperatif tipe Numbered Heads Together (NHT). Karena pembelajaran kooperatif tipe NHT lebih berfokus pada kerja sama siswa dalam kelompok kecil yang beranggotakan 3-5 orang dan dibagi secara heterogen. Jenis penelitian ini adalah penelitian eksperimen dengan pendekatan kuantitatif. Sumber data dari tes hasil belajar siswa berupa pre-test dan posttest. Populasi adalah semua siswa kelas VIII SMP Negeri 1 Bajawa Utara. Sampel yang diambil 10 siswa dengan teknik simple random sampling. Data dianalisis dengan teknik analisis deskriptif dan analisis kovarian (ANAKOVA). Penyusunan perangkat pembelajaran model NHT yang dilakukan menghasilkan perangkat pembelajaran yang baik karena memenuhi syarat validitas, reliabilitas, dan sensitivitas. Hasil analisis kovarian diperoleh statistik $\mathrm{F}$ hitung $=20.29035$ dan $\mathrm{F}$ tabel $=4,45$ dengan $\mathrm{dk}$ pembilang $=1 \mathrm{dan} \mathrm{dk}$ penyebut $=17$, memberikan nilai yang signifikan ( $\mathrm{F}$ hitung $>\mathrm{F}$ tabel). Hal ini menunjukan bahwa model NHT memberikan hasil yang efektif.
\end{abstract}

Kata kunci: model NHT, relasi dan fungsi

Abstract

The problem faced by students in SMPN 1 Bajawa Utara is the lack of student participation in the teaching and learning process because teachers tend to use conventional learning methods, so students do not have the opportunity to think or express opinions either individually or in groups. To overcome these problems, the teacher must choose an appropriate learning method. One of them is cooperative learning type Numbered Heads Together (NHT). Because NHT type of cooperative learning focuses more on student cooperation in small groups of 3-5 people and divided heterogeneously. This type of research is experimental research with a quantitative approach. Sources of data from student learning outcomes tests are pre-test and post-test. The population was all eighth grade students of SMP Negeri 1 Bajawa Utara, samples taken were 10 students using simple random sampling technique. Data were analyzed with descriptive analysis and covariance analysis (ANAKOVA) techniques.The preparation of the NHT model of learning tools carried out produces good learning tools because they meet the requirements of validity, reliability, and sensitivity. The results of covariance analysis obtained statistics $F$ count $=20.29035$ and $F$ table $=4.45$ with the numerator $d k=1$ and the denominator $d=17$, giving a significant value $(F$ arithmetic $>F$ table). This shows that the NHT model gives effective results.

Keywords: NHT model; relationship and function

Copyright (c) 2021 Agnes Pendy, Hilaria Melania Mbagho

$\triangle$ Corresponding author :

Address : Jln. Ahmad Yani

Email : agnespendy@gmail.com

ISSN 2580-3735 (Media Cetak)

Phone : 081237982336

ISSN 2580-1147 (Media Online)

DOI : https://doi.org/10.31004/basicedu.v5i1.542 
166 Model Pembelajaran Numbered Head Together (NHT) pada Materi Pokok Relasi Dan Fungsi - Agnes Pendy, Hilaria Melania Mbagho

DOI: https://doi.org/10.31004/basicedu.v5i1.542

\section{PENDAHULUAN}

Pendidikan adalah upaya membentuk sumber daya manusia yang dapat meningkatkan kualitas hidup. Sumber daya manusia adalah salah satu faktor penting dalam keberhasilan pembangunan di semua bidang. Hingga saat ini pendidikan masih diyakini sebagai wadah dalam pembentukan sumber daya manusia yang diinginkan. (Samidi, 2015) menyatakan belajar adalah perilaku atau upaya seseorang untuk mengubah pola dari mereka yang tidak tahu untuk mengetahui. Belajar juga bisa berarti perubahan pola perilaku dari suatu kegiatan yang dilakukan yang akan diperoleh dari diri sendiri, orang lain di sekitarnya, pendidikan, dan dari latihan dan sebagainya. Belajar adalah bantuan yang diberikan oleh pendidik agar proses memperoleh pengetahuan dapat terjadi, pembentukan sikap dan kepercayaan siswa.

Dalam era globalisasi, pendidikan memiliki peran yang sangat penting. Melalui pendidikan, manusia dituntut untuk dapat mengembangkan segala potensi yang ada dalam diri guna mencapai kesejahteraan hidup sebagaimana yang didambakannya. (Akhmad sudrajat, 2003) Undang-Undang Sistem Pendidikan Nasional Nomor 20 tahun 2003 menyebutkan bahwa pendidikan adalah usaha sadar dan terencana untuk mewujudkan suasana belajar dan proses pembelajaran agar peserta didik secara aktif mengembangkan potensi dirinya untuk memiliki kekuatan spiritual keagamaan, pengendalian diri, kepribadian, kecerdasan, akhlak mulia, serta keterampilan yang diperlukan dirinya, masyarakat, bangsa dan negara.
Dalam pendidikan formal, Matematika merupakan salah satu mata pelajaran yang memegang peranan penting dalam membentuk siswa menjadi berkualitas, karena Matematika merupakan suatu sarana berpikir untuk mengkaji sesuatu secara logis dan sistematis. Keberhasilan kegiatan pembelajaran Matematika dapat diukur dari keberhasilan siswa yang mengikuti kegiatan tersebut. Keberhasilan itu dapat dilihat dari tingkat pemahaman, penguasaan materi, dan prestasi belajar siswa. Semakin tinggi pemahaman, penguasaan materi, dan prestasi belajar maka semakin tinggi pula tingkat keberhasilan pembelajaran.

Pendidikan merupakan media yang sangat berperan untuk menciptakan manusia yang berkualitas dan berpotensi, melalui pendidikan akan terjadi proses pendewasaan diri sehingga di dalam proses pengambilan keputusan terhadap suatu masalah yang dihadapi selalu disertai dengan rasa tanggung jawab yang besar. Mengingat peran pendidikan tersebut maka sudah seyogianya aspek ini menjadi perhatian pemerintah dalam rangka meningkatkan sumber daya masyarakat Indonesia yang berkualitas.

Untuk meningkatkan mutu pendidikan, pemerintah berupaya mencakup seluruh faktorfaktor pendidikan seperti: pengadaan buku ajar, peningkatan kualitas guru, pembaharuan kurikulum, dan proses pembelajaran. Faktor-faktor yang mempengaruhi dalam proses pendidikan itu sering juga disebut dengan komponen-komponen pendidikan. Komponen-komponen pendidikan tersebut, yaitu: siswa atau peserta didik (row input), guru dan non guru, administrasi sekolah, 
167 Model Pembelajaran Numbered Head Together (NHT) pada Materi Pokok Relasi Dan Fungsi - Agnes Pendy, Hilaria Melania Mbagho

DOI: https://doi.org/10.31004/basicedu.v5i1.542

kurikulum, anggaran pendidikan, sarana dan prasarana, corak kebudayaan, kondisi ekonomi, masyarakat sekitar, kependudukan dan politik. Semua komponen tersebut dapat berpengaruh terhadap proses pendidikan, baik secara langsung maupun tidak langsung.

Matematika merupakan salah satu mata pelajaran wajib yang diajarkan mulai dari pendidikan dasar sampai dengan perguruan tinggi. Mengingat begitu pentingnya mata pelajaran Matematika, maka sejak tahun 2002 Matematika diujikan secara nasional dan merupakan salah satu mata pelajaran penentu kelulusan siswa. Meskipun demikian, usaha pemerintah untuk memajukan pendidikan khususnya Matematika belum membuahkan hasil yang optimal. Ini terlihat dari masih rendahnya hasil belajar Matematika siswa.

Materi mata pelajaran Matematika yang diajarkan pada jenjang SMP adalah relasi dan fungsi. Adapun kompetensi dasar yang harus dikuasai siswa pada materi relasi dan fungsi di kelas VIII meliputi: (1) mendeskripsikan dan menyatakan relasi dan fungsi dengan menggunakan berbagai representasi (kata-kata, tabel, grafik, diagram, dan persamaan) (KD 3.3); (2) menyelesaikan masalah yang berkaitan dengan relasi dan fungsi dengan menggunakan berbagai representasi (KD 4.3) (Kemendikbud, 2016) Kompetensi dasar yang harus dikuasai mengingat materi tersebut merupakan dasar untuk materi berikutnya. Namun fakta di sekolah menunjukan masih ada siswa yang belum menguasai kompetensi dasar tersebut. Menurut guru Matematika yang bersangkutan hal ini terjadi karena selama proses pembelajaran berlangsung aktivitas siswa cenderung diam, pasif, ketika mengalami kesulitan dalam proses pembelajaran siswa tidak bertanya maupun menyampaikan pendapat pada guru.

Permasalahan yang juga dihadapi oleh siswa di SMPN 1 Bajawa Utara yakni kurangnya partisipasi siswa dalam proses belajar mengajar disebabkan guru cenderung menggunakan metode pembelajaran yang masih bersifat konvensional, sehingga siswa tidak mendapat kesempatan untuk berpikir maupun mengungkapkan pendapat baik secara individu ataupun kelompok.

Rendahnya hasil belajar dan kesulitan dalam belajar Matematika juga disebabkan oleh metode penyampaian guru dalam mengelola pembelajaran yang kurang efektif (Somakim, 2003). Sehingga pembelajaran di sekolah belum bisa membuat siswa menjadi aktif di dalam kelas. Padahal keaktifan siswa dalam belajar merupakan kunci keberhasilannya dalam belajar. Peran aktif siswa dalam pembelajaran merupakan suatu keharusan, hal ini sejalan dengan Permendiknas RI No. 41 Tahun 2007 yang menyatakan bahwa proses pembelajaran pada setiap satuan pendidikan dasar dan menengah harus interaktif, inspiratif, menyenangkan, menantang, dan memotivasi peserta didik untuk berpartisipasi aktif serta memberikan ruang yang cukup bagi prakarsa, kreativitas, dan kemandirian sesuai dengan bakat, minat, dan perkembangan fisik serta psikologis peserta didik. Belajar akan mencapai suatu tingkat keberhasilan jika anak bisa memahami makna apa yang dipelajarinya.

Peranan aktif siswa sangat diperlukan dalam proses pembelajaran Matematika karena dengan 
168 Model Pembelajaran Numbered Head Together (NHT) pada Materi Pokok Relasi Dan Fungsi - Agnes Pendy, Hilaria Melania Mbagho

DOI: https://doi.org/10.31004/basicedu.v5i1.542

demikian maka proses pembelajaran yang siswa alami akan lebih bemakna dan memberi kesan yang kuat, sehingga materi pelajaran yang diajarkan akan lebih mudah diingat dan dipahami serta proses pembelajaran dapat berlangsung dengan baik. Slameto, (2013) menyatakan bahwa untuk menghasilkan belajar yang efektif diperlukan cara mengajar yang efektif. Di antara syarat-syarat yang diperlukan agar terciptanya mengajar yang efektif adalah siswa yang belajar secara aktif. Salah satu model pembelajaran yang memberikan peluang terjadi proses aktif siswa, mengkontruksi atau membangun sendiri pengetahuannya, pemanfaatan sumber belajar secara beragam, dan memberi peluang siswa bekerjasama adalah pembelajaran kooperatif.

Model pembelajaran adalah sebuah pendekatan, srategi, metode, teknik ataupun taktik dalam suatu proses pembelajaran yang dimana pembelajaran sudah terangkai menjadi satu kesatuan yang utuh maka terbentuklah suatu model pembelajaran. (Akhmad sudrajat, 2008) dalam pembelajaran sains ada banyak model pembelajaran yang mungkin dapat digunakan seperti pembelajaran konvensional dan model pembelajaran Numbered Head Together (NHT).

Pembelajaran kooperatif tipe numbered head together ini dapat melatih kerjasama antar siswa, menjadikan siswa lebih aktif dalam proses pembelajaran dan dengan model kooperatif tipe numbered head together ini siswa dapat belajar mengenai suatu konsep atau topik dalam suasana yang menyenangkan. Model kooperatif tipe numbered head together ini adalah sebuah model pembelajaran yang mengedepankan kepada aktivitas siswa dalam mencari, mengolah dan melaporkan sebuah informasi dari berbagai sumber yang pada akhirnya dipresentasikan di depan kelas (Apriyani, Margiati, \& Anasi, n.d.). Dalam sebuah pembelajaran kooperatif dikenal sebagai tipe numbered head together yang dimana pada dasarnya merupakan sebuah varian yang diskusi kelompok dengan ciri-ciri khasnya yaitu guru menunjuk salah satu siswa yang bisa mewakili kelompoknya tanpa memberi tahu dahulu siapa yang akan mewakili kelompoknya. (Marti, Syamswisna, \& Ganda Putri Panjaitan, 2016).

Pembelajaran dengan model Numbered Heads Together (NHT) akan menumbuhkan kerja sama antar peserta didik, peserta didik berlomba untuk aktif dalam kegiatan pembelajaran karena peran anggota kelompok sangat penting dalam proses pembelajaran. Selain kerja sama antar peserta didik dengan peserta didik, juga akan terjalin kerja sama antara guru dengan peserta didik. Ngatini, (2012) bahwa model pembelajaran Numbered Head Together (NHT) mengajarkan kepada peserta didik agar dapat bekerja sama dan selalu siap untuk memberikan jawaban terhadap pertanyaan yang diberikan guru. Dengan hal ini maka peserta didik akan menjadi termotivasi dan lebih disiplin dalam mengerjakan tugas dan memperhatikan apa yang diinstruksiskan guru sehingga hasil belajar akan menjadi baik

Numbered Head Together (NHT) adalah salah satu strategi pembelajaran kooperatif. Menurut Sohimin, (2013) numbered head together adalah model pembelajaran kelompok yang setiap anggota kelompoknya bertanggung jawab atas kelompoknya, sehingga tidak ada pemisahan 
169 Model Pembelajaran Numbered Head Together (NHT) pada Materi Pokok Relasi Dan Fungsi - Agnes Pendy, Hilaria Melania Mbagho

DOI: https://doi.org/10.31004/basicedu.v5i1.542

antara satu siswa dan siswa lain dalam satu antara satu dan yang lainnya. Sedangkan menurut Istarani, (2012), numbered head together adalah serangkaian pengiriman materi menggunakan konsep kelompok sebagai wadah untuk menyatukan persepsi/ pemikiran siswa terhadap pernyataan yang dibuat atau disampaikan oleh guru, yang kemudian akan dipertanggungjawabkan oleh siswa sesuai dengan nomor permintaan guru dari masing-masing grup. Berdasarkan uraian di atas penulis membuat kesimpulan bahwa penyampaian materi menggunakan kelompok dengan jumlah masing-masing sesuai dengan urutan sebagai wadah dalam menyatukan persepsi/ pemikiran siswa terhadap pertanyaan yang diajukan atau diajukan sehingga dapat meningkatkan hubungan sosial antar siswa.

Model pembelajaran kooperatif menurut teori pembelajaran konstrukstivis, satu prinsip paling penting dalam psikologi pendidikan adalah bahwa guru tidak hanya sekedar memberikan pengetahuan kepada siswa. Siswa harus membangun sendiri pengetahuan di dalam benaknya. Guru dapat memberikan kemudahan untuk proses ini, dengan memberi kesempatan siswa untuk menemukan atau menerapkan ide-ide mereka sendiri, dan mengajar siswa menjadi sadar dan secara sadar menggunakan strategi mereka sendiri untuk belajar. Guru dapat memberi siswa anak tangga yang membawa siswa ke pemahaman yang lebih tinggi, dengan catatan siswa sendiri yang harus memanjat anak tangga tersebut. (Trianto, 2007). Slavin, (2008) bahwa pembelajaran kooperatif adalah pembelajaran yang dilakukan secara berkelompok, siswa dalam satu kelas dijadikan kelompok-kelompok kecil yang terdiri dari 4 sampai 5 orang untuk memahami konsep yang difasilitasi oleh guru dengan memperhatikan keberagaman anggota kelompok. Jadi pembelajaran kooperatif merupakan model pembelajaran yang mengutamakan kerjasama di antara siswa untuk mencapai tujuan pembelajaran

Pengertian model pembelajaran tipe Numbered Head Together (NHT). Menurut Trianto, (2007) Numbered Head Together (NHT) adalah merupakan jenis pembelajaran kooperatif yang dirancang untuk mempengaruhi pola interaksi siswa dan sebagai alternatif terhadap struktur kelas tradisional. Numbered Head Together (NHT) pertama kali dikembangkan oleh Spencer Kagen, (1993) untuk melibatkan lebih banyak siswa dalam menelaah materi yang tercakup dalam suatu pelajaran dan mengecek pemahaman mereka terhadap isi pelajaran tersebut. Penerapan pembelajaran kooperatif tipe NHT merujuk pada konsep Kagen (dalam Ibrahim 2000), dengan tiga langkah yaitu: 1) pembentukan kelompok, 2) diskusi masalah, 3) tukar jawaban antar kelompok.

Langkah-langkah tersebut kemudian dikembangkan oleh Ibrahim (2000) menjadi enam langkah sebagai berikut:

Langkah 1. Persiapan

Dalam tahap ini guru mempersiapkan rancangan pelajaran dengan membuat Rencana Pelaksanaan Pembelajaran (RPP), Lembar Kerja Siswa (LKS) yang sesuai dengan model pembelajaran kooperatif tipe NHT. 
170 Model Pembelajaran Numbered Head Together (NHT) pada Materi Pokok Relasi Dan Fungsi - Agnes Pendy, Hilaria Melania Mbagho

DOI: https://doi.org/10.31004/basicedu.v5i1.542

Langkah 2. Pembentukan kelompok

Dalam pembentukan kelompok disesuaikan dengan model pembelajaran kooperatif tipe NHT. Guru membagi para siswa menjadi beberapa kelompok yang beranggotakan 3-5 orang siswa. Guru memberi nomor kepada setiap siswa dalam kelompok dan nama kelompok yang berbeda. Kelompok yang dibentuk merupakan percampuran yang ditinjau dari latar belakang sosial, ras, suku, jenis kelamin dan kemampuan belajar. Selain itu, dalam pembentukan kelompok digunakan nilai tes awal (pre-test) sebagai dasar dalam menentukan masing-masing kelompok.

Langkah 3. Tiap kelompok harus memiliki buku paket atau buku panduan

Dalam pembentukan kelompok, tiap kelompok harus memiliki buku paket atau buku panduan agar memudahkan siswa dalam menyelesaikan LKS atau masalah yang diberikan oleh guru.

Langkah 4. Diskusi masalah

Dalam kerja kelompok, guru membagikan LKS kepada setiap siswa sebagai bahan yang akan dipelajari. Dalam kerja kelompok setiap siswa berpikir bersama untuk menggambarkan dan meyakinkan bahwa tiap orang mengetahui jawaban dari pertanyaan yang telah ada dalam LKS atau pertanyaan yang telah diberikan oleh guru. Pertanyaan dapat bervariasi, dari yang bersifat spesifik sampai yang bersifat umum. Dengan belajar secara diskusi maka kegiatan belajar lebih menarik, tidak monoton, sehingga membangkitkan motivasi siswa dalam belajar Matematika.
Langkah 5. Memanggil nomor anggota atau pemberian jawaban

Dalam tahap ini, guru menyebut satu nomor dan para siswa dari tiap kelompok dengan nomor yang sama mengangkat tangan dan menyiapkan jawaban kepada siswa di depan kelas. Hal ini dapat meningkatkan motivasi siswa untuk mengkaji dan menguasai materi karena setiap siswa harus siap ketika dipanggil untuk mempresentasikan hasil diskusi di depan kelas

Langkah 6. Memberi kesimpulan

Guru bersama siswa menyimpulkan jawaban akhir dari semua pertanyaan yang berhubungan dengan materi yang disajikan. Berdasarkan beberapa pendapat di atas dapat ditarik kesimpulan bahwa model pembelajaran kooperatif tipe NHT adalah model pembelajaran yang dilakukan secara berkelompok beranggotakan 4-5 orang siswa dimana guru memberi nomor kepada setiap siswa dalam kelompok. Kelompok yang dibentuk mempunyai tingkat kemampuan bervariasi. Setiap anggota kelompok diberi tanggung jawab untuk memecahkan masalah atau soal yang telah diberi sesuai dengan nomor-nomor yang telah ada. Anggota kelompok saling menjelaskan kepada sesama teman anggota kelompoknya, sehingga semua anggota kelompok mengetahui jawaban dari semua soal yang diberikan. Selanjutnya, guru menyebut satu nomor para siswa dari tiap kelompok dan yang telah disebut nomornya harus menyiapkan jawabannya untuk seluruh kelas dan mempresentasikan di depan kelas. 
171 Model Pembelajaran Numbered Head Together (NHT) pada Materi Pokok Relasi Dan Fungsi - Agnes Pendy, Hilaria Melania Mbagho

DOI: https://doi.org/10.31004/basicedu.v5i1.542

Kooperatif tipe NHT (Numbered Heads Together) dikembangkan oleh Spencer Kagen untuk melibatkan lebih banyak siswa dalam menelaah materi yang tercakup dalam satu pelajaran dan mengecek pemahaman mereka terhadap isi pelajaran tersebut. Sebagai gantinya mengajukan pertanyaan kepada seluruh kelas. Siswa lebih banyak dilibatkan dalam menelaah materi yang tercakup dalam suatu pelajaran dan menguji pemahaman mereka terhadap isi pelajaran, selain itu model pembelajaran kooperatif tipe Numbered Head Together (NHT) dapat digunakan untuk meningkatkan penguasaan akademik (Ibrahim, 2000).

Pembelajaran kooperatif tipe NHT merupakan salah satu tipe pembelajaran kooperatif yang menekankan pada struktur khusus yang dirancang untuk mempengaruhi pola interaksi siswa dan memiliki tujuan untuk meningkatkan penguasaan akademik. Tipe ini dikembangkan, dengan melibatkan para siswa dalam menelaah bahan yang tercakup dalam suatu pelajaran dan mengecek pemahaman mereka terhadap isi pelajaran tersebut.

Ibrahim, (2000) mengemukakan tiga tujuan yang hendak dicapai dalam pembelajaran kooperatif dengan tipe NHT yaitu: 1) Hasil belajar akademik stuktural: bertujuan untuk meningkatkan kinerja siswa dalam tugas-tugas akademik. 2) Pengakuan adanya keragaman: bertujuan agar siswa dapat menerima temantemannya yang mempunyai berbagai latar belakang. 3) Pengembangan keterampilan social: bertujuan untuk mengembangkan keterampilan sosial siswa.
Keterampilan yang dimaksud antara lain berbagi tugas, aktif bertanya, menghargai pendapat orang lain, mau menjelaskan ide atau pendapat, bekerja dalam kelompok dan sebagainya. Pada konsep Kagen dalam (Ibrahim, 2000). Penerapan pembelajaran kooperatif tipe NHT merujuk dengan tiga langkah yaitu:1) pembentukan kelompok, 2) diskusi masalah, 3) tukar jawaban antar kelompok

Metode Numbered Head Together (NHT) dalam pembelajaran Matematika pada materi relasi dan fungsi. Metode ini merupakan salah satu bentuk pembelajaran kooperatif yang menuntut siswa untuk bekerja sama dalam suatu kelompok kecil untuk menuntaskan materi pelajarannya. Metode Numbered Head Together (NHT) adalah suatu pendekatan yang dikembangkan oleh Spencer Kagen, (1993) untuk melibatkan lebih banyak siswa dalam menelaah materi yang tercakup dalam suatu pelajaran dan mengecek pemahaman mereka terhadap isi pelajaran tersebut (Ibrahim, 2000). NHT merupakan bentuk variasi dari diskusi kelompok, dimana setiap siswa dalam kelompok mendapat nomor.

Menurut Ibrahim, (2000), pada metode ini guru menggunakan struktur 4 langkah yaitu: penomoran, mengajukan pertanyaan, berpikir bersama dan menjawab. Sedangkan menurut Mastudar, (2005) metode NHT mempunyai beberapa langkah yaitu: membuat kelompok, membagi tugas pada tiap kelompok, diskusi kelompok dan menjawab pertanyaan sesuai dengan nomor yang dipanggil serta menyimpulkan bersama.

Salah satu keunggulan dari NHT adalah setiap siswa mendapat kesempatan berekspresi dan 
172 Model Pembelajaran Numbered Head Together (NHT) pada Materi Pokok Relasi Dan Fungsi - Agnes Pendy, Hilaria Melania Mbagho

DOI: https://doi.org/10.31004/basicedu.v5i1.542

mengeluarkan pendapat, dengan adanya penomoran pada NHT lebih membuat kesiapan siswa dalam proses pembelajaran menjadi baik, karena pada saat presentasi kelompok siswa tidak tahu siapa yang mendapat kesempatan untuk menyajikan materi di depan kelas. Pemilihan pembelajaran kooperatif tipe NHT pada materi relasi dan fungsi, diharapkan siswa akan terlibat secara aktif dalam proses pembelajaran, seperti percaya diri untuk bertanya baik pada teman maupun guru dan memberikan tanggapan pada kelompok kecil maupun diskusi kelas. Selain melibatkan keaktifan siswa, model pembelajaran kooperatif tipe NHT dipilih dibandingkan pembelajaran kooperatif tipe lainnya adalah adanya pemberian nomor pada anggota kelompok, karena menurut peneliti model ini lebih mengecek kesiapan siswa karena setiap siswa dituntut untuk bertanggung jawab atas jawaban kelompoknya. Dengan adanya kerjasama dalam kelompok diharapkan dapat mendorong siswa untuk mengembangkan pikiran, pengalaman, serta partisipasi aktif mereka dalam belajar sehingga terjalin interaksi belajar antar siswa dengan harapan dapat meningkatkan aktivitas dan hasil belajar Matematika siswa. Prestasi belajar siswa menjadi lebih baik dan dapat meningkatkan kualitas pembelajaran Matematika.

Hasil belajar merupakan tolak ukur atau patokan untuk menentukan keberhasilan siswa dalam mengetahui dan memahami suatu materi yang telah dipelajarinya. Hasil belajar juga dapat memberikan informasi kepada lembaga ataupun siswa itu sendiri tentang taraf penguasaan dan kemampuan yang dicapai siswa, yang berkaitan

dengan materi dan keterampilan mengenai materi pelajaran yang telah diberikan.

Penilaian hasil belajar siswa dapat meningkatkan motivasi belajar siswa dan umpan balik bagi siswa. Seseorang yang memperoleh nilai bagus dalam sebuah penilaian akan dapat memberikan dorongan bagi orang tersebut dan diharapkan mereka lebih giat dan tekun dalam mengikuti proses pengajaran.

NHT berbeda dengan cara pembelajaran kelompok biasa. Pada pembelajaran kelompok biasa yang mempresentasikan hasil kerja kelompok atau laporan kelompok bebas. Boleh disampaikan oleh salah seorang anggota kelompok. Tetapi pada NHT yang harus mempresentasikan hasil kerja kelompok atau laporan kelompok adalah nomor yang dipilih secara acak oleh guru, sehingga setiap siswa dalam kelompok merasa bertanggung jawab dalam diskusi kelompok. Rumusan masalah dalam penelitian ini adalah apakah hasil belajar Matematika siswa yang menggunakan metode NHT lebih baik dari pada hasil belajar

Oleh karena itu peneliti tertarik untuk mengkaji model pembelajaran NHT pada materi Relasi dan Fungsi pada siswa kelas VIII SMPN 1 Bajawa Utara.

Penelitian yang relevan dan mempunyai keterkaitan dalam penelitian ini adalah sebagai berikut.

1. Berdasarkan penelitian yang dilakukan oleh Rahmi, S.O dan Adnan, F (2019) dengan judul "Penerapan Model Pembelajaran Kooperatif Tipe Numbered Head Together (NHT) Terhadap Hasil belajar Siswa Kelas 
173 Model Pembelajaran Numbered Head Together (NHT) pada Materi Pokok Relasi Dan Fungsi - Agnes Pendy, Hilaria Melania Mbagho

DOI: https://doi.org/10.31004/basicedu.v5i1.542

IV SDN 43 Sungai Sapih Padang” bahwa menggunakan model pembelajaran numbered head together memiliki rerata 83,41 hasil belajar dan siswa yang menggunakan pembelajaran konvensional memiliki hasil belajar rata-rata 75,90 , dan hasil uji hipotesis sebesar 0,049 atau <0,05. Jadi dapat disimpulkan bahwa terdapat perbedaan hasil belajar siswa antara penerapan model pembelajaran kooperatif tipe Numbered Head Together (NHT) dengan penerapan pembelajaran konvensional di kelas IV SD Negeri 43 Sungai Sapih Kota Padang.

2. Berdasarkan penelitian yang dilakukan oleh Ikhwandari, Hardjono, \& Airlanda, (2019) dengan judul "Peningkatan Motivasi dan Hasil belajar Matematika Peserta Didik dengan model Numbered Head Together (NHT)" bahwa motivasi dan hasil belajar siswa mengalami peningkatan yang berarti. Motivasi pada pra-siklus I yang mencapai kategori tinggi sebesar $22 \%$ atau 5 dari 23 peserta didik. Setelah dilakukan tindakan siklus I untuk meningkatkan motivasi mencapai kategori tinggi sebesar 52\% atau 12 peserta didik dan pada siklus II untuk lebih meningkatkan motivasi mencapai kategori tinggi sebesar $87 \%$ atau 20 peserta didik. Setelah diberikan tindakan pembelajaran menggunakan model Numbered Head Together (NHT). Setelah diberikan tindakan pembelajaran menggunakan model Numbered Heads Together (NHT), pada siklus I terjadi peningkatan hasil belajar peserta didik yang ditunjukkan oleh kenaikan persentase hasil belajar peserta didik. Sebelum tindakan sebanyak 10 peserta didik (43\%) yang tuntas dari 23 peserta didik. Setelah diberikan tindakan pada siklus I, terjadi peningkatan jumlah yang tuntas menjadi 15 peserta didik (65\%). Pada siklus II terjadi peningkatan jumlah yang tuntas menjadi 20 (87\%). Hasil ini menunjukkkan bahwa adanya peningkatan motivasi dan hasil belajar Matematika peserta didik pada 4 SD Negeri Gedong 2 Banyu Biru dengan menggunakan model Numbered Heads Together (NHT).

\section{METODE}

Jenis penelitian ini adalah penelitian eksperimen yang mengkaji hubungan dua variabel atau lebih dengan melakukan manipulasi atau perlakuan terhadap variabel bebas dan variabel terikat. Dalam pelaksanaan penelitian, siswa dibedakan atas dua kelas yaitu kelas eksperimen dan kelas kontrol. Pada kelas eksperimen dalam proses belajar mengajar menggunakan metode NHT, sedangkan pada kelas kontrol menggunakan pembelajaran konvensional.

Rancangan penelitian yang digunakan randomized control group only design yaitu memilih kelompok eksperimen dan kontrol secara random (Surya Brata, 1998).

Tabel 1. Rancangan Penelitian

\begin{tabular}{ccc}
\hline Kelas & Perlakuan & Tes Akhir \\
\hline Ekperimen & $\mathrm{X}$ & $\mathrm{T}$ \\
Kontrol & - & $\mathrm{T}$ \\
\hline
\end{tabular}


174 Model Pembelajaran Numbered Head Together (NHT) pada Materi Pokok Relasi Dan Fungsi - Agnes Pendy, Hilaria Melania Mbagho

DOI: https://doi.org/10.31004/basicedu.v5i1.542

Populasi dalam penelitian ini adalah dan pada kelas kontrol yang diikuti oleh 20 orang keseluruhan siswa SMPN 1 Bajawa Utara yang berjumlah 134 orang. Pengambilan sampel dilakukan secara acak dengan cara lotting, dengan ketentuan kelas yang terambil pertama adalah kelas eksperimen dan kelas yang terambil kedua adalah kelas kontrol.

Dari hasil pengambilan ditetapkan bahwa kelas eksperimen adalah kelas VIII-2 dan kelas kontrol adalah kelas VIII-1. Instrumen penelitian merupakan alat pengumpulan data yang digunakan dalam suatu penelitian. Instrumen yang digunakan adalah tes hasil belajar Matematika. Adapun teknik analisis data menggunakan uji statistik parametrik yaitu uji perbedaan rerata. Sebelum dilakukan uji statistik parametrik data harus memenuhi uji prasyarat yaitu uji normalitas dan uji homogenitas.

Penelitian dilaksanakan di SMPN 1 Bajawa Utara dari bulan April sampai bulan Mei 2017. Sampel dalam penelitian ini adalah 20 siswa kelas VIII. Adapun prosedur dalam penelitian ini pendefinisian, perancangan, validasi para ahli. Instrumen yang digunakan tes hasil belajar. teknik pengumpulan data teknik tes. Teknik analisis kovarian dengan pengujian kenormalan residual menggunakan uji kolmogorov-smirnov. (Aririz, 2018).

\section{HASIL DAN PEMBAHASAN}

Data hasil penelitian yang dideskripsikan adalah data hasil belajar Matematika yang diperoleh siswa setelah tes akhir dilaksanakan pada kelas eksperimen dan kelas kontrol. Untuk melihat hasil belajar siswa maka diadakan tes akhir pada kelas eksperimen yang diikuti oleh 20 orang siswa siswa. Setelah dilaksanakan tes akhir diperoleh data tentang hasil belajar siswa pada kelas eksperimen dan kelas kontrol.

1) Uji coba untuk melihat validasi, reabilitas dan sensitivitas butir soal

a. Validitas

Hasil perhitungan validitas setiap butir tes dengan menggunakan rumus korelasi product moment disajikan pada table 2 berikut

Tabel 2. Validitas Butir Soal

\begin{tabular}{ccccc}
\hline $\begin{array}{c}\text { Nomor } \\
\text { Soal }\end{array}$ & $\mathbf{1}$ & $\mathbf{2}$ & $\mathbf{3}$ & $\mathbf{4}$ \\
\hline $\boldsymbol{r}_{\boldsymbol{x y}}$ & 0.7484 & 0.6126 & 0.6253 & 0.72496 \\
& 3 & 91 & 2 & 7 \\
Validitas & Tinggi & Tinggi & Tinggi & Tinggi \\
\hline
\end{tabular}

(Arikunto, 2009)

Berdasarkan perhitungan Tabel 1, menunjukan bahwa soal nomor 1, 2, 3 dan 4 memperoleh kriteria tinggi artinya perhitungan mencapai $0,600 \leq r_{x y} \leq 0,800$ maka setiap butir tes dikategorikan valid dan layak digunakan untuk analisis selanjutnya.

b. Reliabilitas

Berdasarkan perhitungan reliabilitas tes diperoleh koofisien dan dapat dilihat pada tabel 3 berikut:

Tabel 3. Reliabilitas Butir Soal THB

\begin{tabular}{lcc}
\hline THB & Koefisien Reliabilitas & Kriteria \\
\cline { 2 - 3 } & \multicolumn{1}{c}{$\mathbf{0 . 4 1 8 7 3}$} & Cukup \\
\hline (Arikunto, 2009) &
\end{tabular}


175 Model Pembelajaran Numbered Head Together (NHT) pada Materi Pokok Relasi Dan Fungsi - Agnes Pendy, Hilaria Melania Mbagho

DOI: https://doi.org/10.31004/basicedu.v5i1.542

Berdasarkan tes hasil reliabilitas, yang terdapat pada Tabel 2 diperoleh koefisien reliabilitas tes 0,418 "cukup", sehingga layak digunakan dalam analisis selanjutnya. Jadi instrumen penelitian ini memenuhi kriteria reliabel dan dapat digunakan untuk analisis selanjutnya. (Arikunto, 2009) .

\section{c. Sensitivitas}

Hasil perhitungan sensitivitas setiap butir soal disajikan dalam tabel 4 berikut:

Tabel 4. Sensitivitas Butir Soal

\begin{tabular}{lllll}
\hline Max & $\mathbf{2 5 . 0 0}$ & $\mathbf{2 5 . 0 0}$ & $\mathbf{2 5 . 0 0}$ & $\mathbf{2 5 . 0 0}$ \\
\hline Min & 10.00 & 15.00 & 15.00 & 10.00 \\
Jum-Skor & 165.00 & 185.00 & 215.00 & 215.00 \\
Skor Tot & 250 & 250 & 250 & 250 \\
& $\mathbf{0 . 6 6}$ & $\mathbf{0 . 7 4}$ & $\mathbf{0 . 8 6}$ & $\mathbf{0 . 8 6}$ \\
Sensitvitas & Peka & Peka & Peka & Peka \\
\hline
\end{tabular}

(Arikunto, 2009).

Berdasarkan analisis data dapat dilihat pada taraf kepercayaan $95 \%(\alpha=0,05)$ diperoleh $p$ value $=0,016$. Karena $p$ value $>$ a maka tolak $\mathrm{H}_{0}$ dan terima $\mathrm{H}_{1}$, sehingga dapat disimpulkan bahwa hasil belajar Matematika siswa yang menggunakan meode NHT lebih baik dari pada hasil belajar Matematika siswa yang menggunakan pembelajaran konvensional.

Berdasarkan kegiatan penelitian yang dilakukan, penulis dapat rasakan perbedaan antara siswa yang menggunakan metode NHT dengan siswa yang menggunakan pembelajaran konvensional. Siswa yang menggunakan metode NHT lebih berada pada kondisi siap belajar, karena mereka telah mendiskusikan materi pelajaran yang akan dipelajari dan materi penunjangnya. Selanjutnya dalam kegiatan belajar mengajar keaktifan siswa jauh lebih baik dari pada siswa yang menggunakan pembelajaran konvensional. Suasana belajar kelas eksperimen pun lebih aktif dan kondusif dibandingkan dengan kelas kontrol.

Penggunaan metode NHT dalam pembelajaran Matematika mengakibatkan siswa menjadi lebih aktif dalam kegiatan belajar, meningkatkan kreativitas serta keterlibatan siswa dalam proses belajar mengajar. Hasil belajar Matematika siswa yang menggunakan metode NHT juga lebih baik dari pada hasil belajar Matematika siswa yang menggunakan pembelajaran konvensional dan dapat dipercaya pada taraf kepercayaan 95\%. Dengan demikian hipotesis penelitian dapat diterima dengan $\alpha=0,05$.

Berdasarkan perhitungan tabel 4, menunjukkan bahwa semua butir tes memenuhi kriteria sensitivitas peka karena hasil interprestasi mencapai $\geq 0,30$. Hal ini berarti semua butir tes memenuhi kriteria sensitif sehingga layak digunakan untuk analisis selanjutnya.

Dari output di atas, untuk menguji efek pembelajaran dalam kelompok eksperimen terhadap respon Y setelah dimurnikan dari variabel konkomitan $\mathrm{X}$, diperoleh statistik $\mathrm{F}=20.29035$ dengan $\mathrm{dk}$ pembilang $=1 \mathrm{dan} \mathrm{dk}$ penyebut 17 , memberikan nilai yang signifikan ( $\mathrm{F}$ tabel $=4,45$ ).

Plot normalitas residual menunjukkan tidak ada penyimpangan terhadap distribusi normal. Hal 
176 Model Pembelajaran Numbered Head Together (NHT) pada Materi Pokok Relasi Dan Fungsi - Agnes Pendy, Hilaria Melania Mbagho

DOI: https://doi.org/10.31004/basicedu.v5i1.542

ini diperkuat dengan menggunakan uji kolmogorov- smirnov yang memberikan $p$ value $=$ 0,567>0,05 sehingga gagal tolak $\mathrm{H}_{0}$ atau residual berdistribusi normal.

\section{SIMPULAN}

Berdasarkan hasil analisis dan pembahasan dapat disimpulkan bahwa hasil belajar Matematika siswa yang menggunakan metode Numbered Head Together (NHT) lebih baik dari pada hasil belajar Matematika siswa yang menggunakan pembelajaran konvensional. Serta dapat penulis kemukakan saran, diharapkan guru Matematika dapat menggunakan metode NHT dalam pembelajaran Matematika dan dapat melakukannya pada pokok bahasan yang lain. Serta untuk peneliti berikutnya diharapkan dapat memperhatikan komponen-komponen lain yang dapat meningkatnya hasil belajar siswa.

\section{DAFTAR PUSTAKA}

Akhmad sudrajat. (2003). Definisi Pendidikan Menurut UU SISDIKNAS No 20 Tahun 2003.

Akhmad sudrajat. (2008). Pengertian Pendekatan, Strategi, Metode, Teknik dan Model Pembelajaran. Bandung: Sinar Baru Algensindo.

Apriyani, P., Margiati, K. Y., \& Anasi, P. T. (n.d.). Pengaruh Penerapan Model Pbl Terhadap Hasil Belajar Siswa Kelas X Ips. 1-10.

Arikunto, S. (2009). Desain Pendidikan Karakter : Konsepsi dan Aplikasinya Dalam Lembaga Pendidikan. J. Jakarta: Alfabeta.

Aririz. (2018). Aririz. Uji Kolmogorov Smirnov. Jakarta: Alfabeta.

Ibrahim. (2000). Pembelajaran Kooperatif. Surabaya: Pustaka Media.

Ikhwandari, L. A., Hardjono, N., \& Airlanda, G. S.
(2019). Peningkatan Motivasi Dan Hasil Belajar Matematika Peserta Didik Dengan Model Numbered Heads Together (Nht). Jurnal Basicedu, 3(4), 2101-2112. https://doi.org/10.31004/basicedu.v3i4.283

Istarani. (2012). Model Pembelajaran Inovatif. Medan: Media Persada.

Kemendikbud. (2016). Undang-undang nomor 22 Tahun 2016. Jakarta: Permendikbud.

Marti, M., Syamswisna, S., \& Ganda Putri Panjaitan, R. (2016). Efektivitas Pembelajaran Kooperatif Tipe Nht (Numbered Heads Together) Dengan Media Visual Terhadap Hasil Belajar Siswa Padamateri Organisasi Kehidupan Di Kelas Vii Smp Rehoboth. Jurnal Pendidikan Matematika Dan IPA, 5(2), 21-28. https://doi.org/10.26418/jpmipa.v5i2.13336

Mastudar. (2005). Alternatif Model Model Pembelajaran. Sumatra Barat: Prestasi Pustaka.

Ngatini. (2012). Peningkatan keaktifan dan hasil belajar Matematika tentang fungsi melalui model pembelajaran numbered heads together bagi siswa smp. Manajemen Pendidikan, 7, 151-159.

Rahmi, S.O dan Adnan, F (2019) Penerapan model pembelajaran kooperatif tipe NHT terhadap hasil belajar siswa kelas IV SDN 43 Sungai Sapih Padang. Jurnal Basicedu Vol 3 No 2 Tahun 2019 p-ISSN 2580-3735 e-ISSN 2580-1147

Samidi. (2015). No Title. Jurnal Ilmu Pendidikan Dan Ilmu Sosial, 1(1), 1-15. https://doi.org/10.30596/edutech.v1i01.272

Slameto. (2013). Belajar dan Faktor - Faktor yang Mempengaruhi. Jakarta: Rineka Cipta.

Slavin. (2008). Koopertaif Leraning, Teori, Riset dan Produk. Bandung: Nusa Media.

Sohimin. (2013). Model Pembelajaran Inovatif Dalam Kurikulum 2013. Jogjakarta: Ar-Ruzz Media.

Somakim. (2003). Pengaruh Penerapan eori Belajar Gagne Dalam Pembelajaran Matematika. Forum Kependidikan, 23(1, FKIP UNSRI). 
177 Model Pembelajaran Numbered Head Together (NHT) pada Materi Pokok Relasi Dan Fungsi - Agnes Pendy, Hilaria Melania Mbagho

DOI: https://doi.org/10.31004/basicedu.v5i1.542

Spencer Kagen. (1993). Kooperatif Learning.

Sanjuan Capistrano: Kagan Cooperative Learning.

Surya Brata. (1998). Psiokologi Pendidikan. Jakarta: Rajawali Pers.

Trianto. (2007). Model model Pembelajaran Inovatif Berorientasi Konstruktifistik. Jakarta: Prestasi Pustaka. 